\title{
Artritis Idiopatik Juvenil Kesepakatan Baru Klasifikasi dan Kriteria Diagnosis Penyakit Artritis pada Anak
}

\author{
Arwin AP Akib
}

\begin{abstract}
Klasifikasi dan kriteria diagnosis penyakit reumatik anak sudah sering menimbulkan kontroversi para peneliti dan ahli reumatologi. Dengan berkembangnya spesialisasi reumatologi pediatri dalam ruang lingkup yang luas, maka berbagai ketidaksepahaman tersebut sudah selayaknya diselesaikan dalam suatu kesepakatan. Prakarsa ILAR membuat nomenklatur baru AIJ di Santiago (1994) serta revisi Durban (1997) patut mendapat penghargaan semua pihak karena diharapkan akan dapat menjadi pemersatu untuk mempermudah komunikasi antar dokter dan peneliti.

Kriteria AIJ diharapkan dapat mengidentifikasi kelompok homogen penderita artritis pada anak, untuk mempermudah penatalaksanaan dan penentuan prognosis penderita, serta merancang dan melakukan penelitian di bidang re umatologi pediatri seperti misalnya penelitian imunogenetik dan ilmu kedokteran dasar lainnya, epidemiologi, prognosis, dan uji terapetik. Walaupun pemakaian kriteria Durban di lapangan belum teruji dengan baik, laporan yang sudah ada menunjukkan bahwa tidak tertutup kemungkinan untuk melakukan revisi ulang kriteria AIJ. Dengan demikian maka terpulang kepada kita, apakah akan memakainya sekarang ataukah menunggu sampai keluar revisi berikutnya yang sudah tentu lebih tahan uji.
\end{abstract}

Kata kunci: artritis idiopatik juvenil, klasifikasi diagnostik

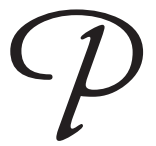

engetahuan tentang penyakit reumatik anak telah dikenal dalam kepustakaan sejak perempat akhir abad 19, dan terus berkembang sampai akhirnya reumatologi pediatri menjadi salah satu spesialisasi ilmu kedokteran saat ini. Sejak awal berkembangnya pengetahuan tentang penyakit reumatik anak tersebut, para peneliti telah membuat klasifikasi dan kriteria diagnosis sendiri yang terkadang tidak selaras sehingga dapat mengganggu pemahaman serta telaah penelitian secara menyeluruh. Berbagai upaya telah dicoba untuk mencapai kesesuaian, tetapi tampaknya sulit untuk membuat kesepakatan tentang klasifikasi dan kriteria

\footnotetext{
Alamat korespondensi: Dr. Arwin AP Akib, Sp.A(K).

Sub Bagian Alergi-ImunologiBagian Ilmu Kesehatan Anak FKUI-RSCM. Jl. Salemba 6, Jakarta 10430.

Telepon: 021-316 1144, Fax.: 3913982.
}

diagnosis penyakit reumatik anak. Dari berbagai klasifikasi tersebut yang paling berpengaruh dan sering dipertentangkan adalah skema yang dibuat oleh American College of Rheumatology (ACR, dahulu bernama American Rheumatism Association=ARA) tentang juvenile rheumatoid arthritis (artritis reumatoid juvenil=ARJ), dan oleh European League Against Rheumatism (EULAR) tentang juvenile chronic arthritis (artritis kronik juvenil=AKJ). ACR lebih memandangnya sebagai kelompok penyakit reumatoid pada anak, sedangkan EULAR mempelajarinya sebagai artritis kronik.

Kesepakatan Durban oleh International League Against Rheumatism (ILAR) tahun 1997 (publikasi 1998), merupakan hasil upaya mempertemukan kelompok peneliti penyakit reumatik anak Eropa dan Amerika Utara dengan membuat kriteria klasifikasi dan diagnosis juvenile idiopathic arthritis (artritis idiopatik juvenil=AIJ). Klasifikasi AIJ diharapkan dapat menggantikan posisi ARJ maupun 
AKJ sehingga lebih mempermudah telaah pustaka serta rancangan penelitian dasar untuk menentukan diagnosis, prognosis, dan tata laksana artritis kronik pada anak.

\section{Penyakit Reumatik Anak}

Reumatologi pediatri mempelajari berbagai kelainan sistim muskuloskeletal yang terjadi pada anak, dan saat ini telah berkembang menjadi spesialisasi sendiri yang menarik banyak minat para spesialis terutama di Amerika Utara dan Eropa. Pada dasarnya perbedaan antara penyakit anak dan dewasa disebabkan oleh proses tumbuh dan kembang yang terjadi pada anak. ${ }^{1}$ Untuk penyakit reumatik perbedaan tersebut berhubungan dengan perkembangan sistim limfoid sampai masa remaja yang akan diikuti kemudian oleh involusi bertahap. Selain itu terdapat pula perbedaan derajat maturitas tulang pada setiap tahap perkembangan anak. Perbedaan fisis dan biokimiawi tulang rawan dan tulang, anatomi serta peran suplai darah untuk metafisis dan epifisis terhadap pertumbuhan tulang, akan sangat mempengaruhi gambaran penyakit reumatik anak. Faktor lain seperti imaturitas gonad, pajanan terhadap antigen, serta ekspresi imunogenetik berperan pula terhadap manifestasi penyakit reumatik anak.

Artritis pada anak dapat disebabkan oleh berbagai penyakit yang mempunyai spektrum sangat luas, yang secara sederhana dapat dikelompokkan menjadi 1) penyakit reumatik dan kondisi yang berhubungan, 2) artritis infeksi, 3) gangguan muskuloskeletal kongenital, 4) gangguan muskuloskeletal didapat non-reumatik, 5) penyakit keganasan, dan 6) penyakit lain seperti penyakit sickle cell, hemofilia dan koagulopati lainnya, hipotiroidisme, sarkoidosis. ${ }^{4}$ Penyakit reumatik anak sendiri terdiri lagi dari ARJ/AKJ atau AIJ, dermatomiositis, lupus eritematosa sistimik, penyakit jaringan ikat campuran, vaskulitis sistimik, skleroderma, spondiloartropati, artritis yang berhubungan dengan penyakit defisiensi imun, dan artritis reaktif (demam reumatik dan artritis yang berhubungan dengan infeksi Gram negatif). Penyakit tersering pada kelompok reumatik anak tersebut adalah ARJ/AKJ/AIJ.

Seperti halnya dengan klasifikasi ARJ dan AKJ, maka klasifikasi dan kriteria diagnosis AIJ juga merupakan kriteria eksklusi sehingga untuk mengenalnya dalam salah satu kategori AIJ membutuhkan pengenalan berbagai penyakit reumatik tersebut. Sejauh ini tidak ada pemeriksaan laboratorium tertentu yang dapat dikatakan spesifik untuk diagnosis AIJ. Pemeriksaan penunjang umumnya bermanfaat untuk menemukan atau menyingkirkan penyakit lain karena sesungguhnya tidak ada pemeriksaan khusus untuk diagnosis AIJ, termasuk pemeriksaan ANA dan faktor reumatoid (FR) maupun pencitraan. Dengan demikian maka anamnesis yang teliti terhadap kelainan bengkak sendi, nyeri terutama pada pergerakan, serta gerakan sendi terbatas atau kaku sendi, menjadi sangat penting. Bila deskripsi keluhan tersebut dapat didokumentasi dengan benar maka pada $82 \%$ anak akan ditemukan kelainan objektif sendi yang sesuai dengan artritis.

Data dari sebagian besar sentra reumatologi anak di Amerika Serikat menunjukkan bahwa sebagian besar keluhan sendi pada anak berhubungan dengan trauma dan infeksi sehingga data tentang trauma dan infeksi harus dicatat dengan baik. Sehubungan dengan itu terlihat pula bahwa oligoartritis pada anak umumnya berhubungan dengan infeksi, trauma, atau kelainan hematologi; sedangkan poliartritis biasanya berhubungan dengan penyakit reumatik terutama artritis reaktif (demam reumatik), atau penyakit limfoproliferatif.

\section{Klasifikasi Penyakit Artritis Kronik pada Anak}

Sebagian besar etiologi dan patogenesis penyakit reumatik anak belum diketahui dengan baik, maka dasar utama pembuatan klasifikasi adalah gejala klinis ditunjang oleh riwayat penyakit, pengamatan perjalanan penyakit dan pemeriksaan fisis, laboratorium, pencitraan, serta patologi. Klasifikasi dan kriteria tersebut perlu dibuat untuk menegakkan diagnosis dan merancang strategi pengobatan, serta menentukan prognosis. Dari berbagai diskusi laporan penelitian yang telah dipublikasi maka pembuatan klasifikasi dan kriteria diagnosis penyakit reumatik anak, khususnya mengenai penyakit artritis kronik, harus mempertimbangkan pula faktor genetik.

Pada saat ini telah diakui bahwa salah satu manfaat aplikasi ilmu kedokteran dasar dalam klinis adalah penerapan imunogenetik dan biologi molekular dalam studi penyakit reumatik anak yang memberi pandangan baru terhadap etiologi dan patogenesisnya. ${ }^{2}$ Hasil studi tersebut tampaknya memberi kemungkinan untuk membuat klasifikasi penyakit reumatik anak secara lebih rasional dan tepat. Klasifikasi yang lebih 
akurat akan memberi jalan bagi pendekatan diagnosis, rancangan pengobatan, dan perkiraan prognosis, menjadi lebih baik. Demikian pula dengan komunikasi antar klinisi/peneliti akan terjalin dengan baik sehingga dapat menghasilkan penelitian yang bermanfaat untuk penatalaksanaan pasien.

Pada umumnya kriteria klasifikasi dan diagnosis penyakit reumatik anak dapat memakai kriteria penyakit reumatik dewasa, kecuali untuk demam reumatik/ penyakit jantung reumatik (DR/PJR) dan ARJ/AKJ yang mempunyai kriteria klasifikasi dan diagnosis sendiri. Penyakit reumatik lain dapat mempunyai nama serta karakter biologis yang sama untuk anak dan dewasa, dan perbedaannya terkadang hanya pada perbedaan frekuensi manifestasi klinis menurut umur, sedangkan ARJ/AKJ atau sub tipenya memang hanya terdapat pada anak dan berbeda dengan dewasa.

\section{Klasifikasi American College Rheuma- tology}

Artritis reumatoid juvenil (ARJ) tidaklah merujuk pada satu penyakit, karena kelainan ini merupakan sindrom dengan berbagai etiologi, dengan serangkaian respons imun tubuh yang saling berkaitan, dan secara karakteristik terlihat sebagai artritis perifer idiopatik. Patogenesisnya ditandai oleh imunoinflamasi yang diduga diaktifkan oleh antigen eksternal. Selain itu ARJ juga mempunyai predisposisi imunogenetik.

Terminologi ARJ mulai dipergunakan secara luas dalam publikasi di Amerika setelah masa perang dunia I dan lebih berkembang lagi sejak akhir tahun 1940-an. Saat ini kriteria ARJ dipergunakan sebagai acuan oleh 4 buku ajar pediatri terkemuka di Amerika Serikat. Terminologi artritis reumatoid juvenil diadopsi ACR dalam kriteria ARJ 1973 dan 1976 dan tetap dipertahankan dengan pertimbangan popularitasnya tersebut. ${ }^{1}$ Klasifikasi dan kriteria ARJ (Tabel 1) telah diuji secara retrospektif serta prospektif dan dilaporkan dalam berbagai publikasi yang makin meningkatkan kemantapan terminologi tersebut. Selama ini hanya klasifikasi dan kriteria ACR yang telah diuji secara prospektif.

Diagnosis ARJ ditegakkan secara klinis tanpa pemeriksaan laboratorium khusus dengan menyingkirkan kemungkinan penyakit lain. Agak di luar dugaan bahwa kriteria diagnosis dengan karakter lemah seperti ini ternyata efektif, karena tindak lanjut selama 5 tahun setelah diagnosis awal, 95\% diagnosis pasien ARJ di berbagai
Tabel 1. Kriteria diagnosis untuk klasifikasi artritis reumatoid juvenil menurut American College of Rheumatology (ACR)

1. Usia onset kurang dari 16 tahun

2. Artritis pada satu sendi atau lebih yang ditandai oleh bengkak atau efusi sendi, atau oleh dua dari gejala kelainan sendi berikut: gerakan sendi terbatas, nyeri atau sakit pada gerakan sendi, dan peningkatan suhu di daerah sendi

3. Lama sakit lebih dari 6 minggu

4. Jenis onset penyakit dalam 6 bulan pertama diklasifikasikan sebagai

a. pausiartikular (oligoartritis): 4 sendi atau kurang

b. poliartritis: 5 sendi atau lebih

c. penyakit sistimik: artritis disertai demam intermiten

5. Penyakit artritis juvenil lain dapat disingkirkan

Dikutip dari Cassidy JT, Petty RE. ${ }^{1}$

sentra reumatologi anak Amerika Serikat tersebut tetap tidak berubah. ${ }^{3}$ Tetapi kesepakatan internasional tentang ARJ masih sulit dicapai mungkin karena kontroversi terhadap istilah reumatoid yang dipergunakan.

\section{Klasifikasi EULAR}

Berbeda dengan ARJ, maka klasifikasi EULAR tentang AKJ (Tabel 2) memasukkan artritis psoriatik,

Tabel 2. Kriteria diagnosis untuk klasifikasi artritis kronik juvenil menurut European League Against Rheumatism (EULAR)

1. Usia onset kurang dari 16 tahun

2. Artritis pada satu sendi atau lebih yang ditandai oleh bengkak atau efusi sendi, atau oleh dua dari gejala kelainan sendi berikut: gerakan sendi terbatas, nyeri atau sakit pada gerakan sendi, peningkatan suhu di daerah sendi

3. Lama sakit lebih dari 3 bulan

4. Jenis onset penyakit setelah 6 bulan diklasifikasikan sebagai:

a. pausiartikular (oligoartritis): 4 sendi atau kurang

b. poliartritis ( 5 sendi atau lebih), FR negatif

c. poliartritis ( 5 sendi atau lebih), FR positif

d. spondilitis angkilosis

e. artritis psoriatik

f. penyakit sistimik: artritis disertai demam intermiten

5. Penyakit artritis juvenil lain dapat disingkirkan

Dikutip dari White $\mathrm{P}^{4}$ 
spondilitis angkilosis, dan artropati yang berhubungan dengan penyakit inflamasi usus, serta menggolongkan artritis reumatoid juvenil sebagai sub tipe AKJ poliartikular dengan FR positif. ${ }^{4}$

Terminologi artritis kronik juvenil mulai diperkenalkan tahun 1977 dan sejak itu istilah kronik untuk penyakit artritis pada anak lebih disukai di Eropa. Para peneliti Eropa umumnya berkeberatan atas pemakaian kata reumatoid karena sesungguhnya AKJ merupakan bentuk klinis penyakit artritis anak yang berbeda dengan reumatoid pada dewasa. ${ }^{5}$ Penggunaan kata reumatoid hanya sesuai untuk sekelompok kecil penyakit artritis kronik juvenil dengan FR positif, dan karena itu tidak sesuai dengan sebagian besar penderita lainnya. Lebih tegas lagi disebutkan bahwa rheumatoid arthritis (artritis reumatoid=AR) pada dewasa bukanlah bentuk lanjut dari penyakit artritis juvenil karena imunopatologi kedua penyakit tersebut berbeda.

\section{Klasifikasi ILAR}

Akibat ketidaksepahaman ACR dan EULAR maka banyak peneliti yang mempergunakan terminologi lain seperti juvenile arthritis (artritis juvenil=AJ), yang sayangnya lebih tidak spesifik dan penuh kerancuan karena akan memasukkan pula penyakit keganasan, kelainan tulang kongenital, dan kelainan hematologi ke dalam kelompok ini. Pada tahun 1994 (Santiago) dan 1997 (Durban), ILAR mencoba menengahi ke dua kutub tersebut dengan membuat nomenklatur baru idiopathic arthritis of chilhood, ${ }^{6}$ dan kemudian juvenile idiopathic arthritis (artritis idiopatik juvenil=AIJ) (Tabel 3). ${ }^{7}$ Istilah ARJ dan AKJ yang sebelum ini banyak membawa ketidaksesuaian telah dihapus. Klasifikasi ILAR dilengkapi pula dengan definisi, eksklusi, dan deskriptor.

Tujuan pembuatan kriteria baru ini adalah untuk mengidentifikasi kelompok homogen penderita artritis kronik pada anak, agar mempermudah penelitian imunogenetik dan ilmu kedokteran dasar lainnya, epidemiologi, prognosis, dan uji terapetik. Telah disetujui bahwa manfaat utama klasifikasi ini sebetulnya adalah untuk mempermudah komunikasi antar dokter dan peneliti. Terminologi artritis idiopatik juvenil diambil sebagai payung untuk menyatakan bahwa kelompok penyakit pada anak dengan karakteristik utama artritis yang menetap paling sedikit selama 6 minggu tersebut, belum diketahui penyebabnya. Istilah kronik maupun reumatoid dihilangkan, dan dengan tegas diakui bahwa etiologi penyakit yang tergolong dalam kelompok tersebut pada saat ini belum diketahui. Bila pada penelitian selanjutnya etiologi terbukti ditemukan maka penyakit tersebut akan dikeluarkan dari kelompok AIJ.

Sejak diperkenalkannya nomenklatur baru AIJ maka media resmi EULAR yaitu Annals of Rheumatic Disease, serta Arthritis and Rheumatism dari ACR telah mempergunakannya dalam berbagai laporan penelitian. Tetapi sampai dengan pertengahan tahun 2001 masih terdapat banyak makalah yang masih mempergunakan terminologi ARJ maupun AKJ, kemungkinan berasal dari penelitian yang sudah dilakukan sebelum AIJ diperkenalkan dan direvisi oleh ILAR. Beberapa buku ajar reumatologi terkemuka tahun terakhir sudah memakai klasifikasi dan kriteria diagnosis Durban walaupun beberapa lainnya masih membahasnya sebagai ARJ atau AKJ.

\section{Evaluasi kriteria diagnosis ILAR (artritis idiopatik juvenil)}

Sebuah studi prospektif telah dilakukan terhadap 202 pasien artritis anak oleh Hoffer dkk. tahun 1977 di Paris untuk evaluasi kriteria Durban, dan 194 di antaranya dapat didiagnosis sebagai AIJ. ${ }^{8}$ Dari 194 penderita AIJ ini, 155 orang (80\%) dapat dimasukkan ke dalam salah satu dari 6 kategori penyakit AIJ, dan 39 orang lainnya $(20 \%)$ tergolong dalam kelompok artritis lain. Dari 39 penderita kelompok artritis lain ini, 17 orang (9\%) tidak sesuai untuk salah satu kategori dan 22 orang (11\%) sesuai dengan dua kategori Durban. Dibandingkan dengan kriteria Durban yang dapat menangkap $80 \%$ AIJ ke dalam salah satu kriteria diagnosisnya, maka dengan kriteria Santiago hanya 120 orang (62\%) yang dapat dikelompokkan ke dalam salah satu kriteria diagnosis.

Perbedaan atau perbaikan tersebut menunjukkan kepada kita bahwa sesungguhnya masih selalu terbuka kemungkinan untuk melakukan revisi terhadap suatu klasifikasi dan kriteria diagnosis penyakit seperti ini. Evaluasi tersebut juga menunjukkan kemampuan kriteria Durban untuk mendiagnosis 33 pasien artritis sistimik (100\%) dibandingkan dengan hanya $3(9 \%)$ yang terdiagnosis dengan kriteria Santiago. Tapi di samping itu Hoffer dkk. juga menemukan kelemahan kriteria Durban yang masih menyisakan 39 (20\%) penderita artritis lain. Karena itu mereka mengusulkan 
Sari Pediatri, Vol. 5, No. 2, September 2003

Tabel 3. Klasifikasi artritis idiopatik juvenil menurut International League Against Rheumatism (ILAR)

\begin{tabular}{ll}
\hline Santiago, 1994 & Durban, 1997 \\
\hline $\begin{array}{l}\text { Sistemik } \\
\text { Definite }\end{array}$ & Sistemik \\
Probable & \\
Oligoartritis & Oligoartritis \\
& - extended \\
Oligoartritis extended & Poliartritis FR negatif \\
Poliartritis FR negatif & Poliartritias FR positif \\
Poliartritis FR positif & Artritis psoriatik \\
Artritis psoriatik & Artritis yang berhubungan dengan entesitis \\
Artritis yang berhubungan dengan entesitis & Artritis lain \\
& $\bullet$ Tidak sesuai dengan salah satu kategori \\
& - Sesuai dengan lebih dari satu kategori \\
\hline
\end{tabular}

\section{Artritis sistemik}

Definisi: artritis dengan demam atau didahului oleh demam paling sedikit 2 minggu, yang terekam sebagai demam quotidian minimal 3 hari, disertai satu atau lebih tanda berikut:

1. Ruam eritem evanescent, tidak menetap (non-fixed)

2. Pembesaran kelenjar getah bening generalisata

3. Hepatomegali atau splenomegali

4. Serositis.

Eksklusi. Eksklusi untuk klasifikasi artritis sistimik tidak dicantumkan, tetapi bila tidak ditemukan tanda klasik penyakit sistimik, maka kemiripan dengan penyakit infeksi atau keganasan harus disingkirkan dengan pemeriksaan laboratorium yang tepat.

\section{Deskriptor.}

1 Usia pada saat onset penyakit

2. Pola artritis selama periode onset (selama 6 bulan pertama sakit)

a. oligoartritis

b. poliartritis

c. artritis timbul setelah 6 bulan pertama kelainan sistimik

3. Pola artritis selama perjalanan penyakit (setelah 6 bulan pertama sakit)
a. oligoartritis
b. poliartritis
c. tanpa artritis setelah 6 bulan pertama sakit

4. Gambaran penyakit sistimik setelah 6 bulan

5. Adanya faktor reumatoid (FR)

6. Kadar protein C-reaktif.

\section{Oligoartritis}

Definisi. artritis pada 1-4 sendi dalam 6 bulan pertama sakit. Terdapat 2 kategori:

1. Oligoartritis persisten: mengenai tidak lebih dari 4 sendi selama perjalanan penyakit

2. Oligoartritis extended: secara kumulatif mengenai 5 sendi atau lebih setelah 6 bulan pertama sakit. Eksklusi.

1. Riwayat psoriasis dalam keluarga, paling sedikit pada tingkat 1 atau 2 pedigri, dengan konfirmasi oleh dermatologis

2. Riwayat penyakit dalam keluarga yang secara medis terbukti berhubungan dengan HLA-B27 paling 
tidak pada tingkat 1 atau 2 pedegri

3. FR positif

4. Anak lelaki HLA-B27 positif dengan onset artritis setelah usia 8 tahun

5. Artritis sistemik.

\section{Deskriptor.}

1. Usia pada saat onset artritis dan psoriasis

2. Pola artritis pada saat 6 bulan dan kunjungan klinik terakhir

a. hanya sendi besar

b. hanya sendi kecil

c. predominan pada tungkai: (i) tungkai atas predominan, (ii) tungkai bawah predominan, (iii)tidak ada predominansi tungkai atas atau bawah

d. keterlibatan sendi spesifik (paha, leher)

e. simetri artritis

3. Adanya uveitis anterior (akut atau kronik)

4. Adanya ANA

5. Alel protektif atau predisposisi HLA kelas I atau II.

\section{Poliartritis FR negatif}

Definisi. artritis mengenai 5 sendi atau lebih selama 6 bulan pertama sakit, uji FR negatif.

Eksklusi.

1. FR positif

2. Artritis sistemik.

Deskriptor.

1. Usia saat onset artritis

2. Simetri artritis

3. Adanya ANA

4. Adanya uveitis (akut atau kronik).

\section{Poliartritis FR positif}

Definisi. artritis mengenai 5 sendi atau lebih selama 6 bulan pertama sakit, dengan uji FR positif pada dua kali pemeriksaan dengan jarak paling sedikit 3 bulan.

Eksklusi.

1. Uji FR negatif pada 2 kali pemeriksaan dengan jarak paling sedikit 3 bulan

2. Artritis sistemik.

\section{Deskriptor.}

1. Usia saat onset artritis

2. Simetri artritis

3. Adanya ANA

4. Karakter imunogenetik (sebanding dengan populasi artritis reumatoid dewasa).

\section{Artritis psoriatik}

Definisi.

1. Artritis dan psoriasis, atau

2. Artritis dan paling sedikit terdapat 2 dari tanda:

a. daktilitis

b. kelainan kuku (pitting atau onikolisis)

c. riwayat psoriasis dalam keluarga, paling sedikit pada tingkat 1 atau 2 pedegri, dengan konfirmasi oleh dermatologis.

Eksklusi.

1. FR positif

2. Artritis sistemik. 


\section{Deskriptor.}

1. Usia saat onset artritis atau psoriasis

2. Pola artritis pada saat 6 bulan setelah onset sakit, dan kunjungan klinik terakhir
a. hanya sendi besar
b. hanya sendi kecil
c. predominan pada tungkai: (i) tungkai atas predominan, (ii) tungkai bawah predominan, (iii)tidak ada predominansi tungkai atas atau bawah
d. keterlibatan tulang punggung
e. keterlibatan sendi sakroiliaka
f. keterlibatan sendi glenohumerus
g. keterlibatan sendi paha
h. keterlibatan sendi sternoklavikula
i. artritis simetri

3. Perjalanan penyakit
a. oligoartritis
b. poliartritis

4. Adanya ANA

5. Uveitis anterior
a. kronik
b. uveitis dengan karakteristik mata nyeri, kemerahan, atau fotofobia

6. Deskriptor HLA.

\section{Artritis yang berhubungan dengan entesitis}

Definisi.

1. Artritis dan entesitis, atau

2. Artritis atau entesitis dengan paling sedikit 2 dari tanda:
a. nyeri sendi sakroiliaka dan/atau nyeri punggung inflamasi
b. adanya HLA-B27
c. riwayat penyakit dalam keluarga yang secara medis terbukti berhubungan HLA-B27 paling tidak pada tingkat 1 atau 2 pedigri
d. uveitis anterior yang biasanya berhubungan dengan mata nyeri, kemerahan, atau fotofobia
e. onset artritis pada anak lelaki setelah usia 8 tahun.

Eksklusi.

1. Psoriasis, paling sedikit pada tingkat 1 atau 2 pedigri, dengan konfirmasi oleh dermatologis

2. Artritis sistemik.

\section{Deskriptor.}

1. Usia saat onset artritis

2. Pola artritis pada saat 6 bulan dan kunjungan klinik terakhir hanya sendi besar
a. hanya sendi kecil
b. predominansi pada tungkai: (i) tungkai atas predominan, (ii) tungkai bawah predominan, (iii) tidak ada predominansi tungkai atas atau bawah
d. keterlibatan tulang punggung
e. keterlibatan sendi sakroiliaka
f. keterlibatan sendi glenohumerus
g. keterlibatan sendi paha

3. Simetri artritis

4. Perjalanan penyakit
a. oligoartritis
b. poliartritis

5. Adanya penyakit inflamasi usus. 
Sari Pediatri, Vol. 5, No. 2, September 2003

\begin{abstract}
Artritis lain
Definisi. Artritis pada anak dengan penyebab tidak diketahui yang menetap paling sedikit 6 minggu, tetapi:

1. Tidak memenuhi kriteria salah satu kategori, atau

2. Memenuhi kriteria lebih dari satu kategori.

Eksklusi. Pasien yang memenuhi kriteria salah satu kategori.

Dikutip dari Petty RE, Southwood TR, Baum J, Bhettay E, Glass DN, Manners P, dkk. Revision of the propose classification criteria for juvenile idiopathic arthritis. ${ }^{7}$
\end{abstract}

sebuah modifikasi kriteria Durban (Tabel 4) yang dapat menangkap 175 pasien (90\%) artritis anak ke dalam salah satu kategori, dan hanya 4 orang yang tergolong sebagai artritis lain ( 1 orang tidak memenuhi salah satu kategori, dan 3 orang yang sesuai untuk 2 kategori).

Menilik evaluasi Hoffer dkk. ini maka dapat kita duga bahwa masih akan ada lagi tanggapan serta usulan perubahan terhadap kriteria Durban, dan pada masanya kelak ILAR harus membuat pertemuan serta revisi lagi. Sementara kita di Indonesia harus mempertimbangkan apakah sudah layak untuk mengikuti kriteria Durban sekarang atau, seperti biasanya, menunggu perkembangan lebih lanjut diskusi para pakar luar negeri.

\section{Tata laksana}

Seperti penatalaksanaan penyakit kronis anak lainnya maka penyakit reumatik anak memerlukan penanganan bersama yang terkoordinasi dan berpusat pada keluarga pasien. Pada dasarnya penatalaksanaan penyakit reumatik anak bertujuan untuk memperoleh

Tabel 4. Usulan modifikasi kriteria Durban

1. Kategori artritis FR positif sebagai pengganti poliartritis FR positif

2. Label baru untuk kategori artritis yang berhubungan dengan entesitis: nyeri spinal inflamasi tidak terbatas pada leher

3. Kriteria eksklusi baru untuk kategori poliartritis FR negatif

a. Entesitis atau sakroiliitis pada anak lelaki berusia lebih dari 8 tahun

b. Psoriasis dan/atau riwayat psoriasis dalam keluarga

4. Kategori baru: artritis psoriatik probable

Dikutip dari Hoffer MF, Mouy R, Prieur AM. Juvenile idiopathic arthritides evaluated prospectively in a single center according to the Durban criteria. $^{8}$ status tumbuh-kembang fisis dan psikologis normal agar dapat menjalani kehidupan seoptimal mungkin. ${ }^{1}$

Upaya pengobatan optimal bila mungkin dilakukan oleh dokter anak ahli reumatologi, perawat, fisioterapis, terapis okupasional, dan petugas sosial. ${ }^{1}$ Selain itu perlu kerjasama dan konsultasi dengan ahli pada bidang oftalmologi, gigi-mulut, ortopedi, kardiologi, psikiatri, nefrologi, dermatologi, serta bidang lain yang sering diminta kerjasamanya. Sokongan terhadap pasien dan keluarga perlu dilakukan oleh ahli psikologi, psikiatri, serta sumber lain dalam komunitas. Bila mungkin dibentuk suatu yayasan atau organisasi yang dapat merangkul dan mempermudah interaksi keluarga pasien, serta kemungkinan untuk memperoleh informasi, pelatihan, atau fasilitas lain yang bermanfaat untuk status tumbuh-kembang normal anak.

Untuk penyakit AIJ maka pada terapi mendikamentosa terdapat kecenderungan membuat protokol pengobatan yang berbeda untuk kelompok oligoartritis, poliartritis, dan sistimik. ${ }^{9}$ Obat antiinflamasi yang telah disetujui untuk dapat diberikan pada anak kecil selama ini hanya asam asetil salisilat, dan kemudian tolmetin serta naproksen, tetapi beberapa sentra mempergunakan juga indometasin atau ibuprofen, serta diklofenak dan sulindak terutama untuk anak besar. Bagian Ilmu Kesehatan Anak FKUI/RSCM, Jakarta memilih naproksen 10$15 \mathrm{mg} / \mathrm{kgBB} / \mathrm{hari}$, atau asam asetil salisilat $75-90 \mathrm{mg} /$ $\mathrm{kgBB} /$ hari untuk anak yang lebih kecil, sebagai antiinflamasi.

Pada tingkat internasional Kelompok Studi Kolaboratif Reumatologi Pediatri saat ini tengah mempelajari penggunaan fenoprofen, ketoprofen, piroksikam, dan meklofenamat pada anak. ${ }^{10}$ Selain itu suntikan kortikosteroid intra-artikular dianjurkan diberi lebih dini terutama bila jelas terdapat disfungsi, nyeri kuat, atau kontraktur fleksi pada AIJ oligoartritis. Berbagai terapi eksperimental telah dilaporkan pula pada anak dengan hasil yang beragam. 


\section{Daftar Pustaka}

1. Cassidy JT, Petty RE. Textbook of pediatric rheumatology. Edisi ke-2. New York: Churchill Livingstone; 1990.

2. Warren RW, Perez MD, Curry MR, Wilking AP, Myones BL. Juvenile idiopathic arthritis. Dalam: Koopman WJ, penyunting. Arthritis and allied conditions. A textbook of rheumatology. Edisi ke-14. Philadelphia: Lippincot Williams \& Wilkins, 2001. h. 1270-93.

3. Cassidy JT. What's in a name? Nomenclature of juvenile arthritis. A North American view. J Rheumatol 1993; 20:4-8.

4. White P. Juvenile chronic arthritis. Clinical features. Dalam: Klippel JH, Dieppe PA, penyunting. Rheumatology. St Louis: Mosby, 1994. h.171-80.

5. Prieur AM. What's in a name? Nomenclature of juvenile arthritis. A European view. J Rheumatol 1993; 20:9-11.

6. Manners PJ. Juvenile rheumatoid arthritis (idiopathic arthritis of childhood). Dalam: Matondang CS, Akib AAP, penyunting. Strategi pendekatan klinis berbagai penyakit alergi dan reumatik pada anak. Naskah lengkap PKB IKA XXXVI. Jakarta: FKUI, 1995. h. 107-15.

7. Petty RE, Southwood TR, Baum J, Bhettay E, Glass DN, Manners P, dkk. Revision of the proposed classification criteria for juvenile idiopathic arthritis: Durban, 1997. J Rheumatol 1998; 25:1991-4.

8. Hofer MF, Mouy R, Prieur AM. Juvenile idiopathic arthritides evaluated prospectively in a single centre according to the Durban criteria. J Rheumatol 2001; 28:1083-90.

9. Sherry DD. Juvenile rheumatoid arthritis. Dalam: Lichtenstein LM, Fauci AS, penyunting. Current therapy in allergy, immunology, and rheumatology. Edisi ke-5. St Louis: Mosby, 1996. h. 194-9.

10. Singsen BH. Juvenile rheumatoid arthritis and pediatric spondyloarthropathies. Dalam: Weisman MH, Weinblatt ME, Louie JS, penyunting. Treatment of the rheumatic diseases. Edisi ke-2. Philadelphia: WB Saunders Company, 2001. h. 403-22. 